\title{
The prevalence of periodontal disease according to oral care habits
}

\author{
Do-Hee Kim¹, Hyun-Ju Chung², and Ok-Su Kim²* \\ ${ }^{1}$ Department of conservative dentistry, School of Dentistry, Chonnam National University, Gwangju 61186, Republic of Korea \\ ${ }^{2}$ Department of Periodontology, School of Dentistry, Chonnam National University, Gwangju 61186, Republic of Korea \\ (Received Mar 6, 2017; Revised version received Mar 24, 2017; Accepted Mar 24, 2017)
}

\begin{abstract}
Periodontal disease is one of the most common chronic diseases. Even though scaling and root planing are helpful for preventing periodontal disease, most people overlook it. So, the purpose of this study was to investigate oral care habits and the prevalence of periodontal disease to improve disease prevention and oral healthcare. This study was based on subpopulation of Donggu, Gwangju, Korea, for people older than 50, where oral examination and panoramic radiography were performed. Oral examination included O'Leary index, BOP (Bleeding on Probing), PD (Probing Depth), and CAL (Clinical Attatchment level). The subjects were 4025 people who responded to a oral health questionnaire. The prevalence of periodontal disease in the subjects were $10.3 \%, 56.1 \%$, and $33.6 \%$ for slight, moderate, and severe periodontitis, respectively. The prevalence of periodontal disease was higher in men and older aged people in general. With respect to oral care habits, when subjects visited a dental center regularly and used oral hygiene devices, the ratio of the O'Leary Index was over $75 \%$, the BOP was less than $25 \%$, and severe PD and CAL ( $\geq 7 \mathrm{~mm}$ ), and the prevalence of periodontal disease was less. Since the prevalence of periodontal disease was higher in male and increased with age, self-motivation about oral care habits, regular dental visits and oral care, such as scaling, root planning, and tooth brushing, are required for these groups. In addition, use of oral hygiene devices, such as dental floss and interdental brushes, is also.
\end{abstract}

KEY WORDS: Bleeding on probing, Clinical attachment level, Donggu study, Oral care habits, Periodontal disease

\section{서 론}

지구촌은 지금 급속하게 늙어가고 있다. 2010년 일본국 립사회보장 인구문제 연구소에서 발표한 ‘인구통계자료집' (http://www.ipss.go.jp)에 따르면 프랑스, 영국은 현재 전체 인구의 $14 \%$ 가 65 세 이상인 고령사회에 접어들었으며, 미 국도 2014년부터는 고령사회로 접어들 것이라고 전망했다. 또한, 일본은 지난 2005년 이후로 이미 인구의 $20 \%$ 가 65 세인 초고령 사회에 접어든 것으로 조사되었다. 한국도 예 외는 아니다. 통계청(http://kostat.go.kr)에 따르면 1980년 고령인구 비율이 $3.8 \%$ 였던 한국은 2013 년 현재 $12.2 \%$ 로 늘었고 2040 년에는 $32.3 \%, 2060$ 년에는 $40.1 \%$ 까지 상승할 것으로 예측됐다.

이와 같은 고령화 흐름에 따른 노인문제로 경제문제와 의료문제가 가장 중요하게 자리 잡고 있다. 세계보건기구

\section{*Corresponding author: Ok-Su Kim}

Department of Periodontology, School of Dentistry, Chonnam National University, 33 Yongbong-ro, Buk-gu, Gwangju 61186, Republic of Korea Tel.: +82-62-530-5640, Fax: +82-62-530-5649

E-mail: periodrk@chonnam.ac.kr
(WHO)의 보고에 따르면 세계의 질병들은 점점 만성화되 고 있으며 의료문제 중 구강건강이 차지하는 부분은 적지 않다[1]. 치주질환은 세계에서 흔한 만성 질환 중 하나이 며 2009년에서 2010년 동안 시행된 미국국민건강영양조 사(NHANES)에 따르면 미국의 65세 이상 인구의 $70.1 \%$ 가 치주질환을 가지고 있는 것으로 보고되었다[2]. Lee 등 [3]에 의하면 2007년부터 2009년에 실시된 4차 국민건강 영양실태조사에서 우리나라의 중등도 이상 치주질환 유병 률은 $71.9 \%$ 였다. 즉 심한 치주질환으로 인해 치아가 발거 된 후 그에 대한 처치로 고가의 임플란트나 틀니 치료비 를 많은 노인들이 부담해야 하는 실정이다.

치주질환은 스케일링과 같은 기본적인 치료로 상당 부 분 예방할 수 있다[4]. 또한 규칙적인 잇솔질과 치실 등의 구강위생용품의 사용으로 치주질환을 감소시킬 수 있다는 보고도 있다[5]. 그럼에도 불구하고 많은 이들이 구강건강 관리를 소홀히 하고 있으며 이러한 인식들을 변화시키고 관심을 이끌어낼 필요가 있다.

이번 연구에서는 치주질환과 관련된 여러 요인들 중에서 광주광역시 동구에 거주하는 중?노년층의 구강관리습관에 따른 치주질환의 유병률을 알고 치주질환의 예방과 구강건 강관리에 대한 동기부여 및 인식의 변화를 돕고자 한다. 


\section{연구대상 및 방법}

\section{연구대상}

2008년부터 2010년까지 광주광역시 동구 계림동, 산수동 및 소태동에 거주하는 50세 이상의 동구민 5621명을 대상으 로 구강검진과 구강관련 설문조사를 실시하였다[6]. 그 중 구 강검사를 모두 받고, 구강건강 관련 설문조사 항목에 빠짐없 이 응답한 4025명에 대한 자료를 연구에 포함시켰다.

\section{연구방법}

설문조사

설문조사는 광주시 동구 만성질환 코호트 연구를 위해 개발된 설문지를 이용하였다. 이번 연구에서 이용한 구강 관련 설문지는 전신 건강 및 구강 건강에 대한 전반적인 질문으로 구성되어있으며 총 12 개의 항목 중 구강관리습 관에 관한 $1,4,8,9$ 번 문항의 총 4 개 항목을 토대로 대상 자들의 구강습관을 파악하였다.

\section{방사선 촬영}

$66 \mathrm{kV}, 9 \mathrm{~mA}, 18.0 \mathrm{~s}$ 의 노출조건에서 대상자들의 파노라 마 방사선(Planmeca ProOne, Planmeca Oy, Helsinki, Finland) 촬영을 시행하였다.

\section{구강검사}

먼저 검사자가 상악과 하악의 편측을 선택하게 하고 치 아가 편중되어있는 경우에는 치아가 있는 쪽을 선택하였 다. 그 후 동전을 던져 윗면이 나오면 좌측, 아랫면이 나

\section{오면 우측을 선택하여 구강검사를 실시하였다.}

구강검사 항목에는 O'Leary 치태지수(O'Leary Index), 탐 침 후 출혈(BOP; Bleeding on Probing), 치주낭 깊이(PD; Probing Depth), 임상부착수준(CAL; Clinical Attatchment level)이 포함되었다.

치면착색제를 이용하여 구강 내 치태를 착색한 후 치아당 근심, 원심, 협측면, 설면 4군데의 치태 유무를 기록하여 O'Leary 치태지수(O'Leary Index)를 평가하였다. Michigan marking 된 치주낭 탐침기(Hu-friedy, Chicago, IL, USA)를 이 용해 각 치아 협설면의 근원심과 중앙부를 포함한 총 6 부위 에서 $\mathrm{mm}$ 단위로 치주낭 깊이(PD; Probing Depth)를 측정하고 탐침 후 출혈(BOP; Bleeding on Probing) 유무를 기록하였다. 또한, 치은 퇴축(Gingival Recession)을 측정하여 임상부착수 준(CAL; Clinical Attatchment level)을 산출하였다.

치주질환 심도(Severity) 평가

임상검사와 방사선 검사를 토대로 치주질환을 경증 (slight)/중등도(moderate)/중증(severe)로 분류하였다.

Armitage(1999)에 의한 치주질환의 기준을 이용하여 임 상적, 방사선학적으로 골소실량을 평가하여 진단하였다. 평균 임상부착수준이 $2 \mathrm{~mm}$ 이내인 경우이면 경증(slight), 3-4 mm인 경우 중등도(moderate), $5 \mathrm{~mm}$ 이상의 경우 중 증(severe) 치주질환으로 진단하였다.

방사선 사진 상으로 평가가 모호한 경우에는 Arbes(1999) 의 기준에 의해 $3 \mathrm{~mm}$ 이상의 임상부착수준 비율로 평가하였 다. $0-33 \%$ 의 경우 경증(slight), $33-67 \%$ 의 경우 중등도 (moderate), $67 \%$ 이상의 경우 중증(severe) 치주질환으로 진

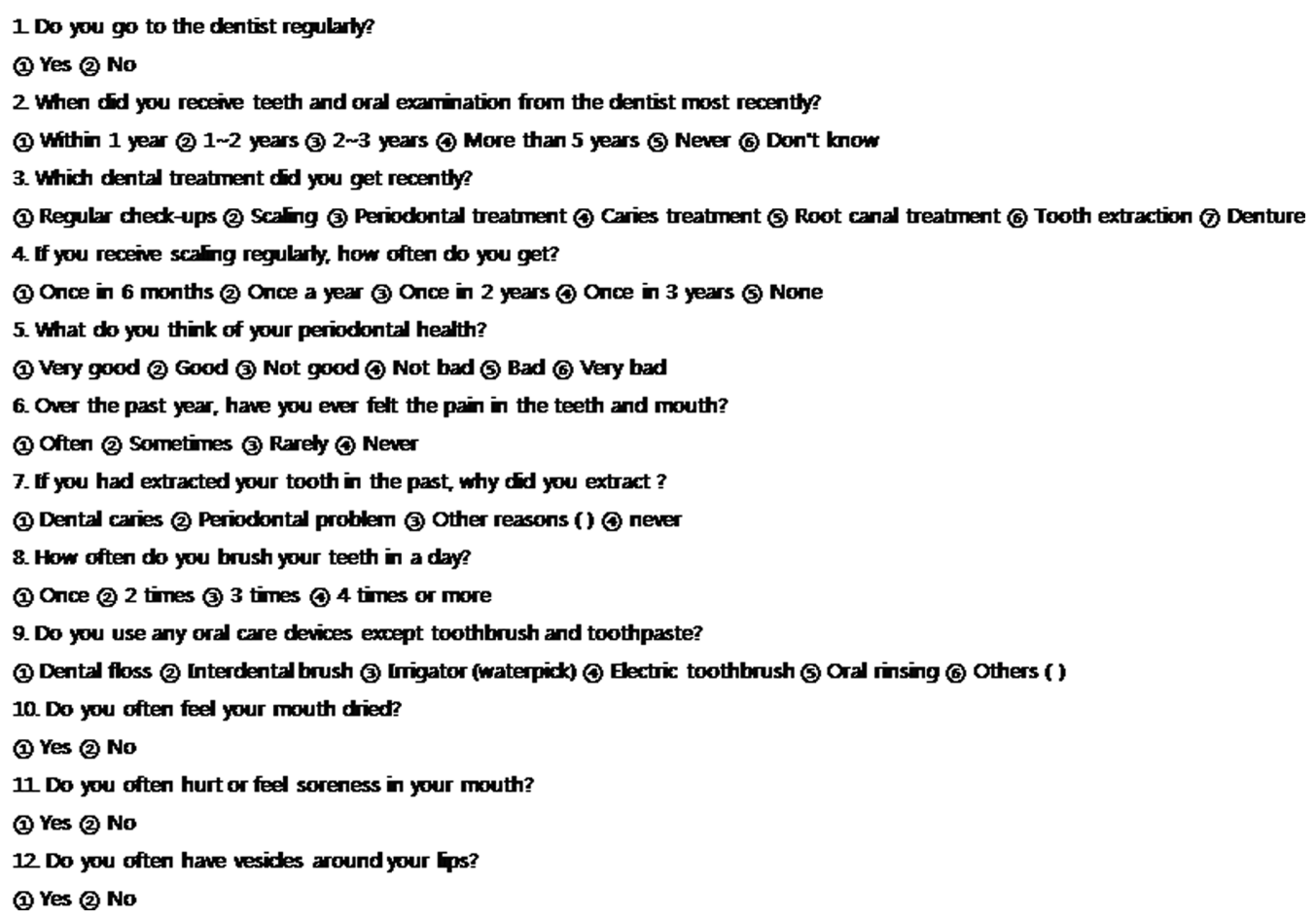

Fig. 1. Oral health Questionnaire. 
단하였다.

\section{통계처리}

SPSS program을 이용하여 구강검사 및 설문에 대한 기술 통계적 분석을 시행하여 연구 집단의 특성을 빈도와 백분율 로 나타내었다. 구강관리습관과 치주질환과의 연관성은 카 이제곱검정과 Tukey와 Duncan의 사후검정을 시행하였다.

\section{결 과}

\section{연구집단의 특징}

2008년부터 2010년 동안 광주광역시 동구 코호트연구에 참가한 50 대 이상 지역민을 대상으로 하였고 구강검진을
받은 5621명 중 구강건강 관련 설문지에 빠짐없이 응답한 4025 명이 포함되었다. 그 중 남성과 여성은 각각 $41.4 \%$,

Table 1. Characteristics of study population

\begin{tabular}{lcc}
\hline & Frequency $(\mathrm{N})$ & Percent (\%) \\
\hline Total & 4025 & - \\
Gender & & \\
Male & 1668 & 41.4 \\
Female & 2357 & 58.6 \\
Age (mean age : 64.9) & & \\
$50-59$ & 1206 & 30 \\
$60-69$ & 1726 & 42.9 \\
$70-79$ & 975 & 24.2 \\
$\geq 80$ & 118 & 2.9 \\
\hline
\end{tabular}

Table 2. O'Leary Index and Bleeding On Probing (BOP) of study population according to oral health care behavior

\begin{tabular}{|c|c|c|c|c|c|c|c|c|}
\hline & \multicolumn{8}{|c|}{ Percent (\%) } \\
\hline & \multicolumn{6}{|c|}{ O'Leary Index } & \multicolumn{2}{|c|}{ BOP } \\
\hline & $0-25 \%$ & $25-50 \%$ & $50-75 \%$ & $75-100 \%$ & $0-25 \%$ & $25-50 \%$ & $50-75 \%$ & $75-100 \%$ \\
\hline Total & 13.7 & 19.9 & 21.4 & 45 & 84.4 & 12.8 & 2.2 & 0.5 \\
\hline \multicolumn{9}{|l|}{ Gender } \\
\hline male & 26 & 18.6 & 16.9 & 38.6 & 84.1 & 12.6 & 2.4 & 0.8 \\
\hline female & 10.5 & 20.3 & 22.5 & 46.7 & 84.6 & 13 & 2.1 & 0.3 \\
\hline \multicolumn{9}{|l|}{ Age } \\
\hline $50-59$ & 10.5 & 18.4 & 22 & 49 & 86.6 & 11.8 & 1.2 & 0.4 \\
\hline $60-69$ & 14.2 & 19.5 & 21.2 & 45 & 84.5 & 12.6 & 2.2 & 0.7 \\
\hline $70-79$ & 15.9 & 23 & 20 & 41.1 & 82 & 14.1 & 3.1 & 0.2 \\
\hline$\geq 80$ & 21.1 & 16.1 & 27.1 & 35.6 & 74.6 & 17.8 & 5.1 & 2.5 \\
\hline \multicolumn{9}{|l|}{ Dental visit } \\
\hline regular visit & 15.1 & 21.3 & 19.3 & 44.2 & 89.9 & 8.4 & 1.4 & 0.3 \\
\hline no & 13.4 & 19.6 & 21.8 & 45.2 & 83.2 & 13.8 & 2.4 & 0.6 \\
\hline \multicolumn{9}{|l|}{ Scaling frequency } \\
\hline once in 6 months & 13.4 & 23.2 & 16 & 47.4 & 91.8 & 7.2 & 0.5 & 0.5 \\
\hline once a year & 15.1 & 22.2 & 18.3 & 44.4 & 88 & 10.4 & 1.3 & 0.3 \\
\hline once in 2 years & 15.1 & 15.1 & 22.1 & 47.7 & 90.1 & 8.1 & 1.7 & 0 \\
\hline once in 3 years & 13.5 & 18.6 & 25 & 43 & 82.8 & 14 & 2.5 & 0.6 \\
\hline none & 13.5 & 19.8 & 21.9 & 44.9 & 83.3 & 13.7 & 2.4 & 0.6 \\
\hline \multicolumn{9}{|l|}{ Brushing frequency } \\
\hline once a day & 12.5 & 16.6 & 18.8 & 52.2 & 77.2 & 16.8 & 4.8 & 1.2 \\
\hline 2 times a day & 13.3 & 19.1 & 21.9 & 45.7 & 85 & 12.6 & 2 & 0.4 \\
\hline 3 times a day & 14 & 21.8 & 21.9 & 42.2 & 85.4 & 12.2 & 1.8 & 0.6 \\
\hline 4 times a day & 19.3 & 22.7 & 16.7 & 41.3 & 86 & 11.3 & 2 & 0.7 \\
\hline \multicolumn{9}{|c|}{ Oral hygiene devices } \\
\hline dental floss & 15 & 26.5 & 24.8 & 33.8 & 92.3 & 6.4 & 0.9 & 0.4 \\
\hline interdental brush & 13.3 & 24.2 & 17.3 & 45.2 & 92.8 & 6.1 & 0.8 & 0.3 \\
\hline irrigator & 5.3 & 0 & 31.6 & 63.2 & 89.5 & 5.3 & 5.3 & 0 \\
\hline electric brush & 11.3 & 18.9 & 34 & 35.8 & 87 & 11.1 & 1.9 & 0 \\
\hline oral rinsing & 18.3 & 30.5 & 17.1 & 34.1 & 89.1 & 9.6 & 1.2 & 0 \\
\hline etc & 13.3 & 22.3 & 23.8 & 40.6 & 79.3 & 16.4 & 3.1 & 1.2 \\
\hline no use & 13.7 & 19.7 & 21.4 & 45.2 & 84 & 13.1 & 2.3 & 0.6 \\
\hline
\end{tabular}


Do-Hee Kim et al.

$58.6 \%$ 로 여성의 비율이 높았으며, 평균 64.9 세로 60 대의

비율이 가장 높았다(Table 1).

\section{구강관리습관과 O'Leary 치태지수}

치면착색제를 도포한 후 측정한 O'Leary Index에 대한
결과는 다음과 같다. O'Leary Index가 $25 \%$ 이하 비율은 치과를 정기적으로 방문하는 사람들은 $15.1 \%$ 로 방문하지 않는 사람들은 $13.4 \%$ 였다. 스케일링을 6 개월에 한 번씩 자주하는 경우(13.4\%)는 1년에 한번(15.1\%), 2년에 한번 (15.1\%) 하는 경우 보다 오히려 O'Leary Index $25 \%$ 이하

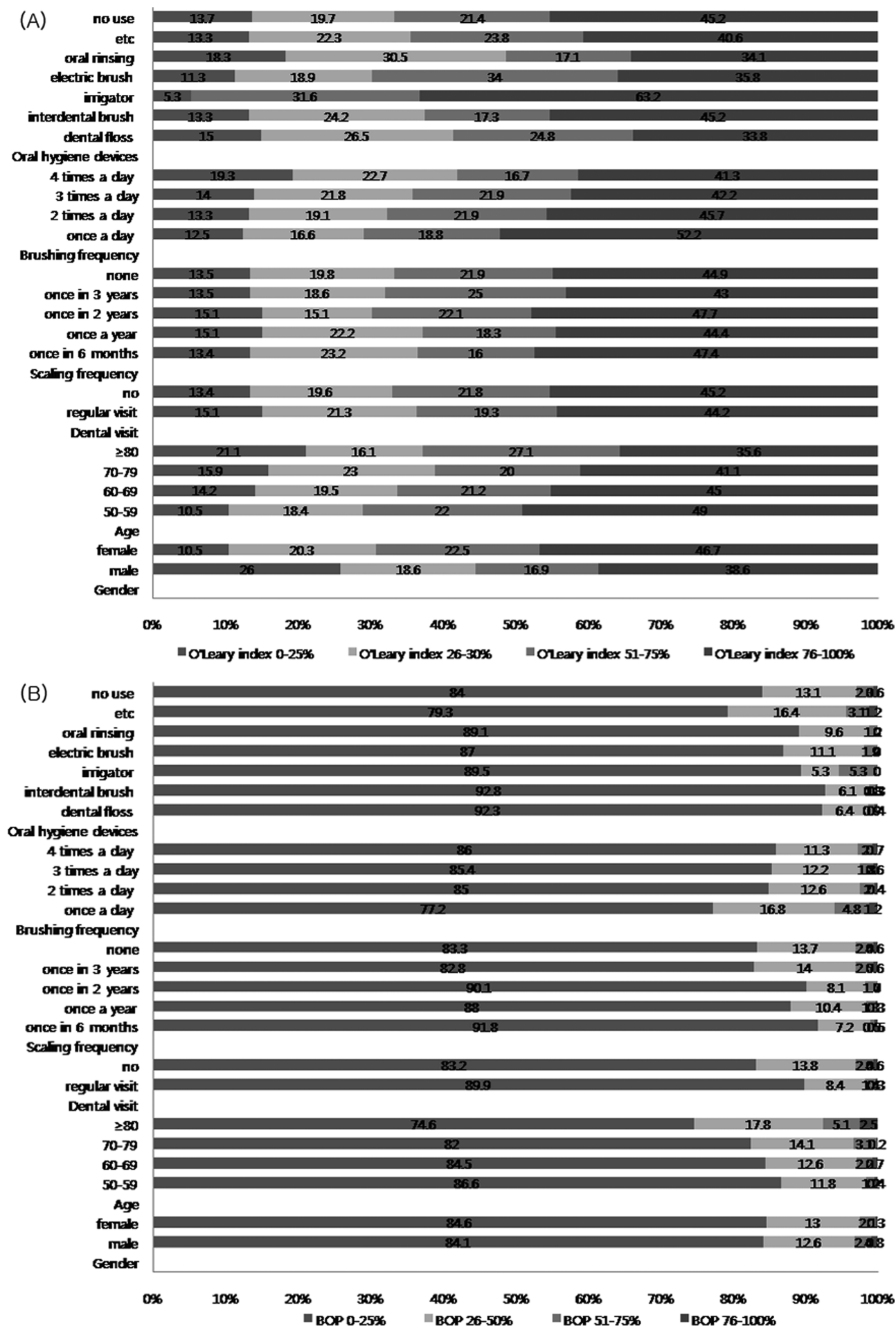

Fig. 2. O'Leary Index and Bleeding On Probing (BOP) of study population acorrding to oral health care behavior (unit: \%) (A) O'Leary Index (B) BOP. 
비율이 낮았으며, 스케일링을 받지 않는 경우 $(13.5 \%)$ 와 거의 비슷했다. 잇솔질을 자주 할수록 O'Leary Index $25 \%$ 이하 비 율은 증가했다. 구강위생용품 중 구강세정액을 사용한 경우 (18.3\%) O'Leary Index $25 \%$ 이하 비율이 가장 컸고, 구강세정 기를 사용한 경우(5.3\%) 현저하게 낮았다(Table 2).

\section{구강관리 습관과 탐침 시 출혈}

치과를 정기적으로 방문한 사람들에 대한 $\mathrm{BOP} 25 \%$ 이
하의 비율(89.9\%)이 치과를 방문하지 않은 사람들에 대한 비율 $(83.2 \%)$ 보다 더 높았다. 스케일링 빈도에 대해서는 6 개월에 1 번 스케일링을 받는 경우 $\mathrm{BOP} 25 \%$ 이하 비율이 가장 높았다(91.8\%). 잇솔질의 경우 하루에 여러 번 할수 록 $\mathrm{BOP} 25 \%$ 이하 비율이 증가하였다. 치실과 치간칫솔을 사용하는 경우는 각각 $92.3 \% 92.8 \%$ 로 구강위생용품을 사 용하지 않는 경우 $84 \%$ 에 비해 BOP $25 \%$ 이하 비율이 크 게 상승했다(Table 2).
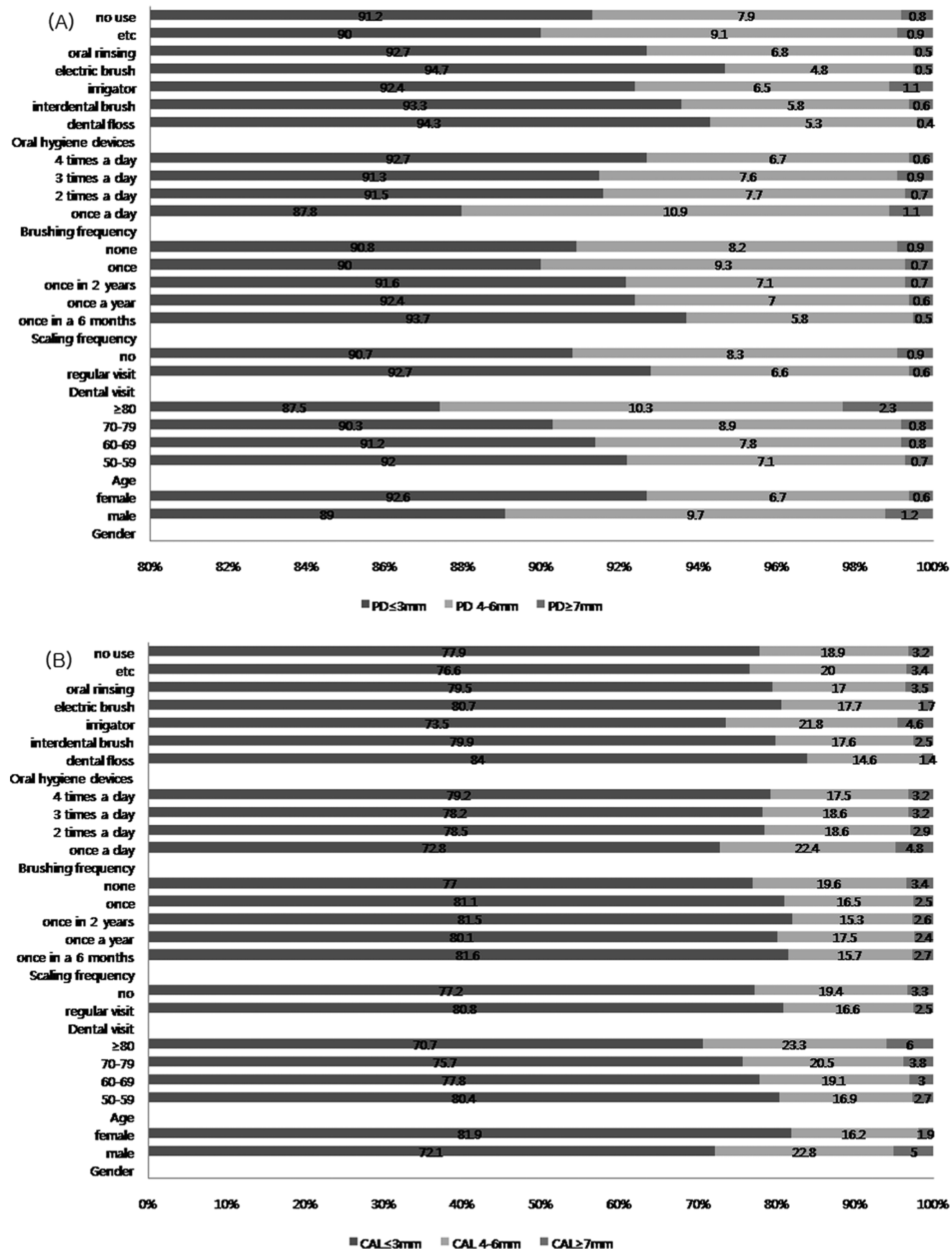

Fig. 3. Mean Pocket Depth (PD) and mean Clinical Attachment Level (CAL) of study population according to oral health care behavior (unit: \%) (A) PD (B) CAL. 


\section{치주낭 깊이와 임상부착수준}

연령이 증가할수록 치주낭 깊이가 $7 \mathrm{~mm}$ 이상이 되는 부 위의 비율이 증가하였다. $\mathrm{PD} \geq 7 \mathrm{~mm}$ 의 비율이 70 대에서 는 $0.8 \%, 80$ 대에서는 $2.3 \%$ 로 3 배 가량 증가하였다. 치과 를 정기적으로 방문한 경우 $\mathrm{PD} \geq 7 \mathrm{~mm}$ 는 $0.6 \%$, 방문하지 않은 경우는 $0.9 \%$ 였다. 스케일링 빈도에 관련해서는 받지
않는 경우에 $\mathrm{PD} \geq 7 \mathrm{~mm}$ 의 비율이 $0.9 \%$ 로 가장 높았다. 잇 솔질은 하루에 1 번 하는 경우 $\mathrm{PD} \geq 7 \mathrm{~mm}$ 의 비율이 $1.1 \%$ 로 가장 높았다. 구강위생용품 중 치실을 사용한 경우 $\mathrm{PD}$ $\geq 7 \mathrm{~mm}$ 의 비율이 $0.4 \%$ 로 가장 낮았으며 구강세정기와 기 타 위생용품을 사용한 경우에는 증가하였다(Table 3).

또한 연령이 증가할수록 임상부착수준 $7 \mathrm{~mm}$ 이상 부위

Table 3. Mean Pocket Depth (PD) and mean Clinical Attachment Level (CAL) of study population according to oral health care behavior

\begin{tabular}{|c|c|c|c|c|c|c|}
\hline & \multicolumn{6}{|c|}{ Mean Percentage (\%) } \\
\hline & \multicolumn{3}{|c|}{ PD } & \multicolumn{3}{|c|}{ CAL } \\
\hline & $\leq 3 \mathrm{~mm}$ & $4-6 \mathrm{~mm}$ & $\geq 7 \mathrm{~mm}$ & $\leq 3 \mathrm{~mm}$ & 4-6 mm & $\geq 7 \mathrm{~mm}$ \\
\hline Total & 91.1 & 8 & 0.8 & 77.8 & 19.9 & 3.2 \\
\hline \multicolumn{7}{|l|}{ Gender } \\
\hline male & 89 & 9.7 & 1.2 & 72.1 & 22.8 & 5 \\
\hline female & 92.6 & 6.7 & 0.6 & 81.9 & 16.2 & 1.9 \\
\hline \multicolumn{7}{|l|}{ Age } \\
\hline $50-59$ & 92 & 7.1 & 0.7 & 80.4 & 16.9 & 2.7 \\
\hline $60-69$ & 91.2 & 7.8 & 0.8 & 77.8 & 19.1 & 3 \\
\hline $70-79$ & 90.3 & 8.9 & 0.8 & 75.7 & 20.5 & 3.8 \\
\hline$\geq 80$ & 87.5 & 10.3 & 2.3 & 70.7 & 23.3 & 6 \\
\hline \multicolumn{7}{|l|}{ Dental visit } \\
\hline regular visit & 92.7 & 6.6 & 0.6 & 80.8 & 16.6 & 2.5 \\
\hline no & 90.7 & 8.3 & 0.9 & 77.2 & 19.4 & 3.3 \\
\hline \multicolumn{7}{|l|}{ Scaling frequency } \\
\hline once in a 6 months & 93.7 & 5.8 & 0.5 & 81.6 & 15.7 & 2.7 \\
\hline once a year & 92.4 & 7 & 0.6 & 80.1 & 17.5 & 2.4 \\
\hline once in 2 years & 91.6 & 7.1 & 0.7 & 81.5 & 15.3 & 2.6 \\
\hline once & 90 & 9.3 & 0.7 & 81.1 & 16.5 & 2.5 \\
\hline none & 90.8 & 8.2 & 0.9 & 77 & 19.6 & 3.4 \\
\hline \multicolumn{7}{|l|}{ Brushing frequency } \\
\hline once a day & 87.8 & 10.9 & 1.1 & 72.8 & 22.4 & 4.8 \\
\hline 2 times a day & 91.5 & 7.7 & 0.7 & 78.5 & 18.6 & 2.9 \\
\hline 3 times a day & 91.3 & 7.6 & 0.9 & 78.2 & 18.6 & 3.2 \\
\hline 4 times a day & 92.7 & 6.7 & 0.6 & 79.2 & 17.5 & 3.2 \\
\hline \multicolumn{7}{|l|}{ Use of dental floss } \\
\hline yes & 94.3 & 5.3 & 0.4 & 84 & 14.6 & 1.4 \\
\hline no & 90.9 & 8.1 & 0.8 & 77.5 & 19.2 & 3.3 \\
\hline \multicolumn{7}{|c|}{ Use of interdental brush } \\
\hline yes & 93.3 & 5.8 & 0.6 & 79.9 & 17.6 & 2.5 \\
\hline no & 90.9 & 8.2 & 0.8 & 77.6 & 19.1 & 3.3 \\
\hline \multicolumn{7}{|l|}{ Use of irrigator } \\
\hline yes & 92.4 & 6.5 & 1.1 & 73.5 & 21.8 & 4.6 \\
\hline no & 91.2 & 8 & 0.8 & 77.9 & 18.9 & 3.1 \\
\hline \multicolumn{7}{|l|}{ Use of electric brush } \\
\hline yes & 94.7 & 4.8 & 0.5 & 80.7 & 17.7 & 1.7 \\
\hline no & 91.1 & 8 & 0.8 & 77.8 & 18.9 & 3.2 \\
\hline \multicolumn{7}{|l|}{ Use of oral rinsing } \\
\hline yes & 92.7 & 6.8 & 0.5 & 79.5 & 17 & 3.5 \\
\hline no & 91.1 & 8 & 0.8 & 77.8 & 19 & 3.2 \\
\hline \multicolumn{7}{|l|}{ etc } \\
\hline yes & 90 & 9.1 & 0.9 & 76.6 & 20 & 3.4 \\
\hline no & 91.2 & 7.9 & 0.8 & 77.9 & 18.9 & 3.2 \\
\hline
\end{tabular}


의 비율이 증가하였다. 80 대에서는 $\mathrm{CAL} \geq 7 \mathrm{~mm}$ 부위의 비율이 $6.0 \%$ 로 그 외 연령대에 비해 2 배 정도 증가하였다. 치과를 정기적으로 방문하지 않는 경우와 정기적으로 스 케일링을 받지 않는 경우에 $\mathrm{CAL} \geq 7 \mathrm{~mm}$ 의 비율이 높았다. 구강세정기와 구강세정액, 기타 구강 위생용품을 사용하 는 경우 $\mathrm{CAL} \geq 7 \mathrm{~mm}$ 부위의 비율이 증가하였다(Table 3 ).

\section{치주질환의 유병률}

이 연구에 포함된 50세 이상 동구민 4025명의 치주질환 유병률은 다음과 같았다. 성별분포는 남성과 여성이 각각 $41.4 \%$ 와 $58.6 \%$ 로 여성의 비율이 더 높았으며, 남성과 여 성 모두에서 중등도의 치주질환 유병률이 높았다. 남성의 경우 여성보다 중증 치주질환 유병률 $46.2 \%$ 로 여성에 비

Table 4. The prevalence of periodontitis for study population

\begin{tabular}{|c|c|c|c|c|c|c|c|}
\hline & \multicolumn{7}{|c|}{ Periodontitis } \\
\hline & \multicolumn{3}{|c|}{ Frequency $(\mathrm{N})$} & \multicolumn{3}{|c|}{ Percent (\%) } & \multirow{2}{*}{ p-value } \\
\hline & Slight & Moderate & Severe & Slight & Moderate & Severe & \\
\hline Total & 415 & 2258 & 1352 & 10.3 & 56.1 & 33.6 & - \\
\hline \multicolumn{8}{|l|}{ Gender } \\
\hline male & 92 & 805 & 771 & 5.5 & 48.3 & 46.2 & \\
\hline female & 323 & 1453 & 581 & 13.7 & 61.6 & 24.6 & 0 \\
\hline \multicolumn{8}{|l|}{ Age } \\
\hline $50-59$ & 202 & 707 & 297 & 16.7 & 58.6 & 24.6 & \\
\hline $60-69$ & 155 & 1009 & 562 & 9 & 58.5 & 32.6 & \\
\hline $70-79$ & 53 & 498 & 424 & 5.4 & 51.1 & 43.5 & \\
\hline$\geq 80$ & 5 & 44 & 69 & 4.2 & 37.3 & 58.5 & 0 \\
\hline \multicolumn{8}{|l|}{ Dental visit } \\
\hline regular visit & 92 & 443 & 190 & 12.7 & 61.1 & 26.2 & \\
\hline no & 323 & 1815 & 1162 & 9.8 & 55 & 35.2 & 0 \\
\hline \multicolumn{8}{|l|}{ Scaling frequency } \\
\hline once in 6 months & 28 & 117 & 49 & 14.4 & 60.3 & 25.3 & \\
\hline once a year & 52 & 220 & 111 & 13.6 & 57.4 & 29 & \\
\hline once in 2 years & 25 & 107 & 40 & 14.5 & 62.2 & 23.3 & \\
\hline once in 3 years & 19 & 96 & 42 & 12.1 & 61.1 & 26.8 & \\
\hline none & 291 & 1718 & 1110 & 9.3 & 55.1 & 35.6 & 0 \\
\hline \multicolumn{8}{|c|}{ Brushing frequency } \\
\hline once a day & 27 & 207 & 182 & 6.5 & 49.8 & 43.8 & \\
\hline 2 times a day & 204 & 1152 & 677 & 10 & 56.7 & 33.3 & \\
\hline 3 times a day & 172 & 808 & 446 & 12.1 & 56.7 & 31.3 & \\
\hline 4 times a day & 12 & 91 & 47 & 8 & 60.7 & 31.3 & 0 \\
\hline \multicolumn{8}{|l|}{ Use of dental floss } \\
\hline yes & 35 & 159 & 41 & 14.9 & 67.7 & 17.4 & \\
\hline no & 380 & 2099 & 1311 & 10 & 55.4 & 34.6 & 0 \\
\hline \multicolumn{8}{|c|}{ Use of interdental brush } \\
\hline yes & 48 & 241 & 87 & 12.8 & 64.1 & 23.1 & \\
\hline no & 367 & 2017 & 1265 & 10.1 & 55.3 & 34.7 & 0 \\
\hline \multicolumn{8}{|l|}{ Use of irrigator } \\
\hline yes & 1 & 12 & 6 & 5.3 & 63.2 & 31.6 & \\
\hline no & 414 & 2246 & 1346 & 10.3 & 56.1 & 33.6 & 0.787 \\
\hline \multicolumn{8}{|c|}{ Use of electric brush } \\
\hline yes & 10 & 29 & 15 & 18.5 & 53.7 & 27.8 & \\
\hline no & 405 & 2229 & 1337 & 10.2 & 56.1 & 33.7 & 0.124 \\
\hline \multicolumn{8}{|l|}{ Use of oral rinsing } \\
\hline yes & 5 & 50 & 29 & 6 & 59.5 & 34.5 & \\
\hline no & 410 & 2208 & 1323 & 10.4 & 56 & 33.6 & 0.388 \\
\hline \multicolumn{8}{|l|}{ Etc } \\
\hline yes & 25 & 146 & 85 & 9.8 & 57 & 33.2 & \\
\hline no & 390 & 2112 & 1267 & 10.3 & 56 & 33.6 & 0.943 \\
\hline
\end{tabular}



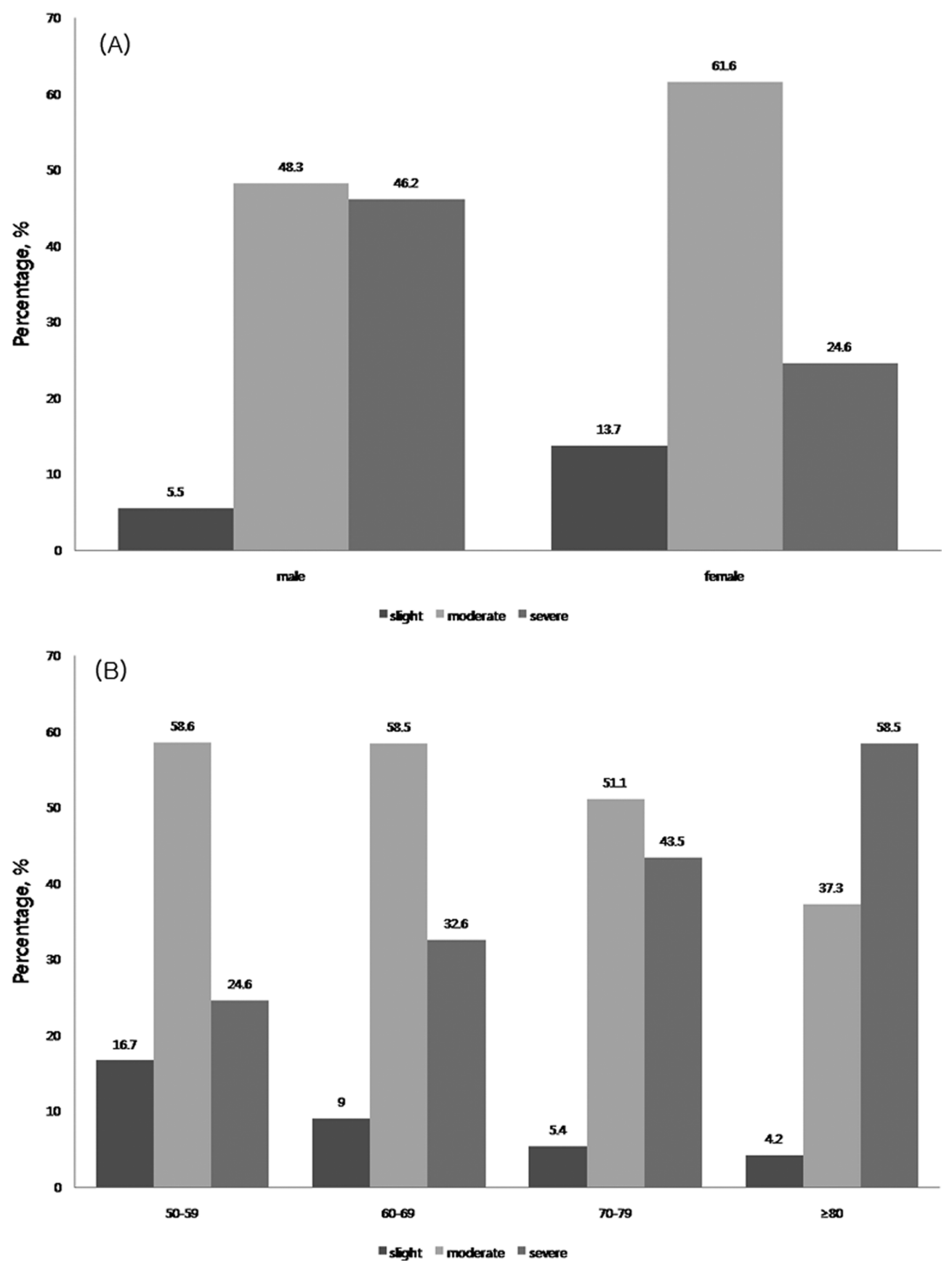

Fig. 4. The prevalence of periodontitis in study population according to gender and age (unit: \%) (A) gender (B) age.

해 거의 2 배 정도 높았다. 연령별 분포는 60 대가 $42.9 \%$ 로 가장 많았으며, 50 대가 $30 \%, 70$ 대가 $24.2 \%, 80$ 대가 $2.9 \%$ 의 순서로 나타났다. 50대, 60대, 70대에서는 중등도 치주 질환 유병률이 더 높았으나, 80대에서는 중증 치주질환 유 병률이 높았다(Table 4, Fig. 4). 구강 건강 설문지에서 정 기적 치과 방문에 관한 문항에 정기적으로 치과를 방문한 다고 응답한 대상자는 $18 \%$ 였으며, 중등도 이상의 치주질 환 유병률이 높았다. 정기적으로 치과를 방문하는 대상자 의 $26.2 \%$ 는 중증 치주질환을 가지고 있었으며, 이는 치과
를 방문하지 않는다고 응답한 대상자들 중 중증 치주질환 을 가진 경우(35.2\%) 보다 낮았다(Table 4, Fig. 5A).

대상집단의 $77.5 \%$ 는 정기적으로 스케일링을 받고 있지 않다고 응답하였으며 이들 중 $35.6 \%$ 가 중증 치주질환을 가지고 있었다. 정기적으로 스케일링을 받는 대상자들 중 에서 중증 치주질환을 가지는 비율은 그렇지 않은 경우보 다 낮았으나, 빈도에 대해서는 1 년에 한번 경우에 $29 \%$ 로 중증 치주질환 유병률이 가장 높았다. 이는 2 년 한번 받는 경우(23.3\%), 3년에 한번 받는 경우(26.8\%) 보다도 오히려 

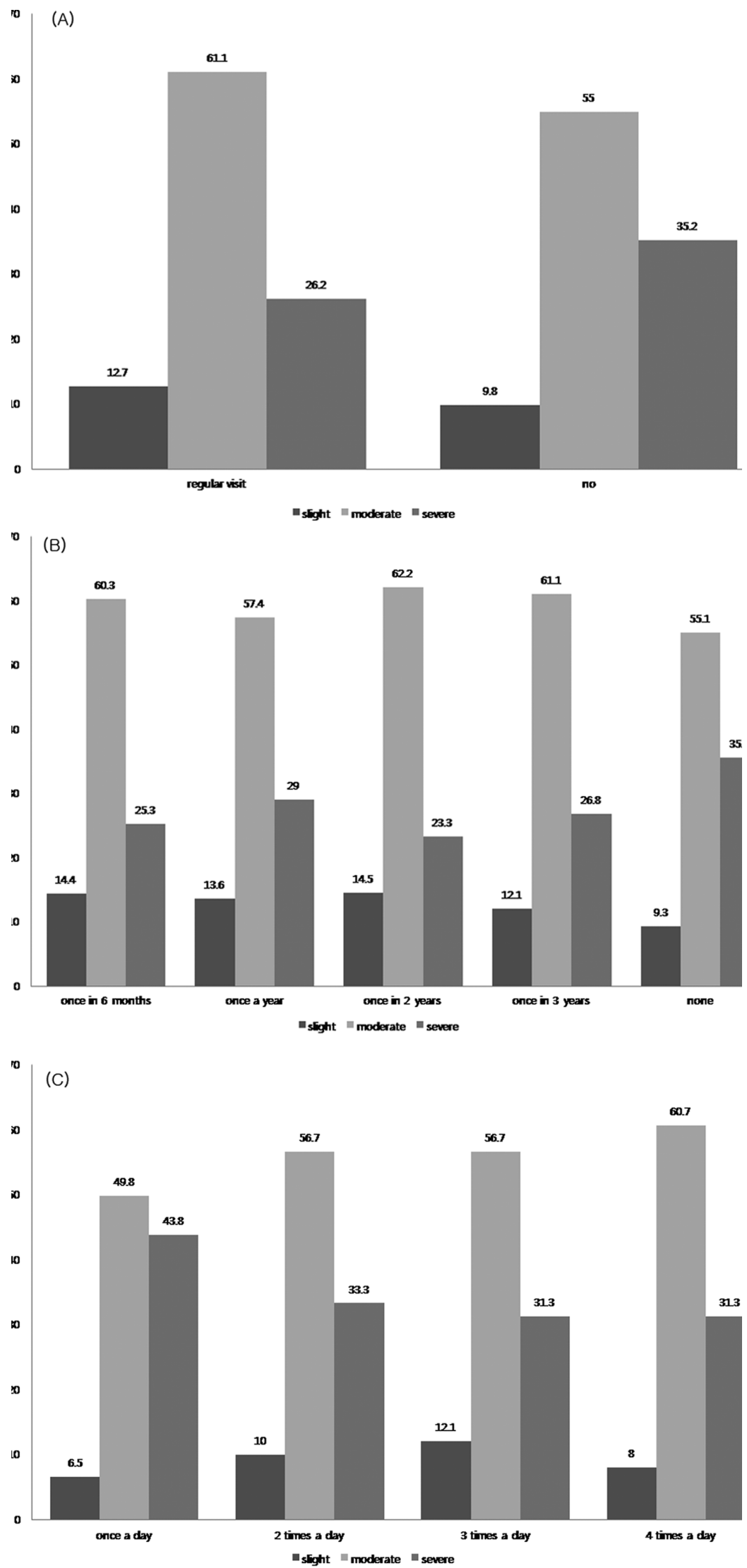

Fig. 5. The oral care habits and the prevalence of periodontitis in study population (unit: \%) (A) dental visit (B) scaling frequency (C) brushing frequency. 


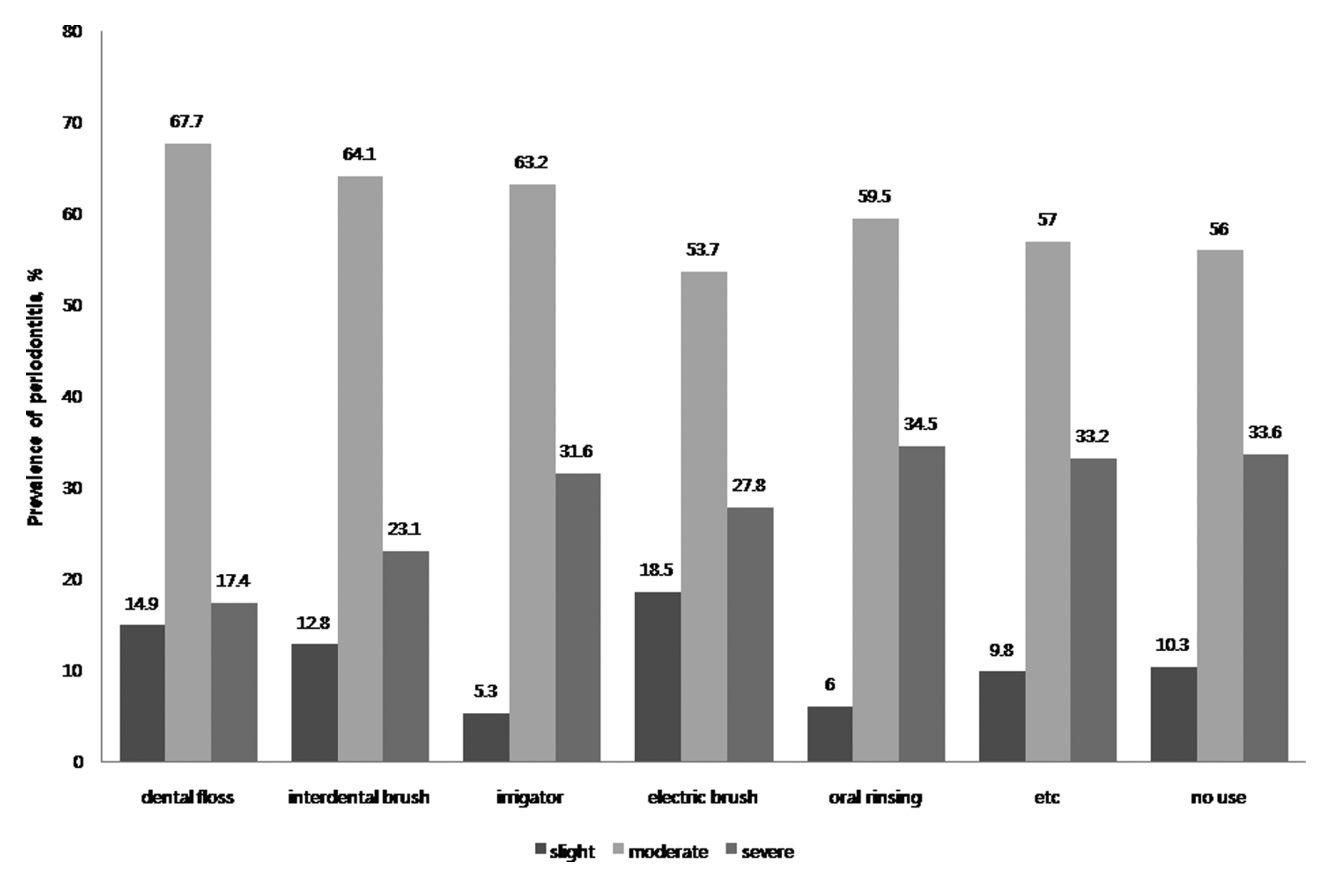

Fig. 6. The use of oral hygine devices and the prevalence of periodontitis in study population (unit: \%).

더 높았다(Table 4, Fig. 5B).

잇솔질은 하루에 2 번 하는 경우가 $50.5 \%$ 로 가장 많았다. 잇솔질을 하루에 1 번만 하는 경우에 중증 치주질환 유병 률이 $43.8 \%$ 로 가장 높았으나 하루에 3 번 하는 경우와 4 번 하는 경우가 $31.3 \%$ 로 중증 치주질환 유병률의 차이는 없 었다(Table 4, Fig. 5C).

대상집단의 대부분 구강위생용품을 사용하지 않았으며, 사용하는 구강위생용품 중에서 치간칫솔을 가장 많이 사 용하였다 $(9.3 \%)$. 중증 치주질환의 유병률은 치실을 사용하 는 경우 $17.4 \%$, 치간칫솔을 사용하는 경우 $23.1 \%$ 로 그 외 의 구강용품을 사용하는 경우에서 보다 낮았다. 또한, 치 실을 사용하지 않는 경우(34.6\%)는 치실을 사용하는 경우 $(17.4 \%)$ 보다 중증 치주질환 유병률이 2 배 정도 더 높았다. 기타 구강용품을 사용하는 경우에는 사용하는 경우와 사 용하지 않는 경우에서 치주질환 유병률의 차이가 거의 없 었다(Table 4, Fig. 6).

\section{구강관리습관과 치주질환 유병률의 상관관계}

카이제곱검정 결과 치주질환의 유병률은 연령, 성별과 관련이 있었다 $(\mathrm{p}=0.000)$. 구강관리습관에 관련해서는 정 기적인 치과방문, 스케일링 빈도, 양치질횟수와 관련이 있었다. 구강위생용품에서는 치실, 치간칫솔에서는 유의 미하였으나 그 외 구강세정기, 전동칫솔, 구강세정액, 기 타 구강위생용품에 대해서는 유의미하지 않았다(p>.05) (Table 4).

치주질환 유병률과의 연관성에 대한 Turkey와 Duncan 의 사후검정 결과 스케일링 빈도에 따라 광주광역시 동구
Table 5. Periodontitis and scaling frequency of the study population in the relevance of the post-hoc test (subgroup 1; scaling frequently, 2 ; scaling sometimes, 3 ; scaling rarely)

\begin{tabular}{|c|c|c|c|c|c|}
\hline \multicolumn{2}{|c|}{ Periodontitis } & \multirow[t]{2}{*}{$\mathrm{N}$} & \multicolumn{3}{|c|}{$\begin{array}{l}\text { significance level }= \\
\text { subgroup for } 0.05\end{array}$} \\
\hline & & & 1 & 2 & 3 \\
\hline & Mild & 415 & $4.1880^{*}$ & & \\
\hline \multirow[t]{3}{*}{ Tukey B ${ }^{a}, b$} & Moderate & 2258 & & $4.3632 *$ & \\
\hline & Severe & 1352 & & & $4.5185^{*}$ \\
\hline & Mild & 415 & $4.1880^{*}$ & & \\
\hline \multirow[t]{3}{*}{ Duncan $^{\mathrm{a}}, \mathrm{b}$} & Moderate & 2258 & & $4.3632 *$ & \\
\hline & Severe & 1352 & & & $4.5185^{*}$ \\
\hline & p-value & & 1 & 1 & 1 \\
\hline
\end{tabular}

*: These values represent the average of the scaling frequency. (1; once in 6 months, 2; once a year, 3; once in 2 years, 4 ; once in 3 years, 5 ; none)

50 대 이상 지역민들은 스케일링을 자주 받는 집단/보통인 집단/자주 받지 않는 집단[평균값이 1에 가까울수록 스케 일링 빈도가 높다 $(1 ; 6$ 개월에 한번, 2 ; 1년에 한번, $3 ; 2$ 년 에 한번, $4 ; 3$ 년에 한번, 5 ;받지 않음)]으로 분류되었고 세 집단 중에서 스케일링을 자주 받지 않는 집단이 상대적으 로 중증 치주질환을 가지고 있었다(Table 5).

잇솔질 횟수에 따라서는 잇솔질을 적게 하는 집단과 자 주 하는 집단[평균값이 4에 가까울수록 잇솔질 빈도가 높다 (1; 하루에 한번, 2; 하루에 2번, 3; 하루에 3번, 4; 하루에 4 번)]으로 분류되었고, 두 집단 중에서 잇솔질을 자주 하지 않는 집단이 중증 치주질환을 가지고 있었다(Table 6). 
Table 6. Periodontitis and brushing frequency of the study population in the relevance of the post-hoc test (subgroup 1; brushing rarely, 2; brusing frequently)

\begin{tabular}{clccc}
\hline \multirow{2}{*}{ Periodontitis } & $\mathrm{N}$ & \multicolumn{2}{c}{$\begin{array}{c}\text { significance level }= \\
\text { subgroup for } 0.05\end{array}$} \\
\cline { 3 - 5 } & & & 1 & 2 \\
\hline \multirow{3}{*}{ Tukey $\mathrm{B}^{\mathrm{a}}, \mathrm{b}$} & Mild & 415 & & $2.402^{*}$ \\
& Moderate & 2258 & & $2.3468^{*}$ \\
& Severe & 1352 & $2.2648^{*}$ \\
\hline \multirow{2}{*}{ Duncan $^{\mathrm{a}}, \mathrm{b}$} & Mild & 415 & & $2.4072^{*}$ \\
& Moderate & 2258 & & $2.3468^{*}$ \\
& Severe & 1352 & $2.2648^{*}$ \\
\hline
\end{tabular}

*: These values represent the average of the brushing frequency. ( 1 ; once in 6 months, 2; once a year, 3 ; once in 2 years, 4 ; once in 3 years, 5 ; none)

\section{고 찰}

이 연구는 2008년에서 2010년 동안 광주광역시 동구 지 역민들을 대상으로 하여 치주질환의 유병률에 관한 자료 를 제공하기 위해 시행하였다. 질환의 유병률에 관한 의미 있는 비교연구를 위해서 조사 대상의 질환에 대한 정의가 중요한 전제조건인데, 치주학 연구에서는 이러한 목적에 부합하는 일정한 기준이 아직 없다[7]. 이번 연구에서는 임상적으로 탐침 시 출혈(BOP), 치주낭 깊이(PD)와 임상 부착수준 $(\mathrm{CAL})$ 을 측정하고 지지 치조골의 방사선학적 평 가를 통해 치주질환의 심도(severity)를 경증(slight)/중등도 (moderate)/중증(severe)으로 분류하였다. Muhleman과 Mazor 는 치은 연하의 염증을 나타내는 첫번째 변화를 탐침 시 출혈(BOP)로 보았다[8]. 즉, $\mathrm{BOP}$ 의 비율이 낮을수록 치주 조직의 염증소견이 경미하고 치주조직이 건강한 것으로 볼 수 있다. 치주조직의 지지상실은 치주낭 깊이 $(\mathrm{PD})$ 와 임 상부착수준 $(\mathrm{CAL})$ 을 측정하여 평가한다. 치주낭 깊이 $(\mathrm{PD})$ 는 치은 변연에서 적당한 힘으로 치주탐침을 치주낭 내로 삽입하여 탐침의 끝이 닿는 거리까지로 정의된다. 임상부 착수준 $(\mathrm{CAL})$ 은 백악-법랑경계부로 부터 삽입된 탐침 끝까 지의 거리이다[7]. 전 세계적으로 세계보건기구(WHO)가 고안한 지역사회치주치료 필요지수(CPITN)을 많이 이용 하고 있으나, 이번 연구에서는 $\mathrm{PD}$ 와 $\mathrm{CAL}$ 을 $3 \mathrm{~mm}$ 이하, 4$6 \mathrm{~mm}, 7 \mathrm{~mm}$ 이상으로 분류하여 비율을 산정하였다. 또한 O'Leary 치태지수(O'Leary Index)를 통해 대상자들의 구강 위생 관리능력을 평가하고자 하였다. O'Leary Index는 치 태의 위치와 양을 나타내주어 환자의 치태관리 능력을 확 인하기에 유용한 지수이다. 구강내 치면을 근심, 원심, 협 면, 설면의 4 부분으로 나누고 치면착색제를 도포하여 착색 된 치면의 수를 전체 검사치면의 수로 나눈 값에 100 을 곱
하여 구한다. O'Leary 등은 자가 관리 교육을 통해 치태지 수를 $10 \sim 15 \%$ 로 줄여야 한다고 하였다[9]. 이에 저자는 BOP 및 O'Leary index의 정도를 확인함에 있어 구강을 4 분악으로 계산하여 $25 \%$ 간격으로 산정하여 결과를 산출 하였다.

치주질환의 유병률에 관련된 여러 가지 요인들 중에서 성별과 연령이 중요하다는 연구들이 많이 있다 $[10,11]$. 2007년에서 2009년 까지 한국에서 시행된 4차 국민건강영 양실태조사(KNHANES)를 토대로 한 Lee 등[3]의 연구에 서는 CPITN code $3(\mathrm{PD} \geq 4 \mathrm{~mm})$ 이상인 경우를 치주질환 으로 보았는데, 이의 연구 대상자들의 평균연령은 44.9 세 였으며 그 중 $51.8 \%$ 가 치주질환을 가지고 있었다. Jordan 의 한 연구에서는 14 세 이상 67 세 이하 인구의 $53.3 \%$ 가 치주질환을 가지고 있었다[12]. 2009년에서 2010년의 미 국국민건강영양조사(NHANES)에 따른 연구에서 미국의 65세 이상 인구의 $53 \%$ 는 중등도(moderate), $11.2 \%$ 는 중증 (severe) 치주질환을 가지고 있다고 보고했다[2]. 태국의 50 세 이상 73 세 이하 인구의 치주질환의 유병률은 경증 (slight)이 $30.5 \%$, 중등도(moderate)가 53.6\%, 중증(severe) 이 $15.9 \%$ 였다[13]. 이번 연구의 평균연령은 64.9 세로 그 중 $56.1 \%$ 가 중등도(moderate) 치주질환을 가지고 있었으 며, $33.6 \%$ 는 중증(severe) 치주질환을 가지고 있었다. 광주 광역시 동구 지역의 유병률이 앞에서 언급된 연구들 보다 높았던 것은 이번 연구의 대상자들의 평균 연령이 더 높 았기 때문으로 보인다. 실제로 여러 연구에서 연령에 따라 치주질환의 유병률이 증가한다는 보고들이 있다. 미국[2], Jordan[12]과 태국[13]의 연구를 비롯하여 스웨덴[11]의 보 고에서도 연령에 따라 치주질환 유병률이 유의미하게 증 가하였다. 독일의 Pomerania 지역의 PD와 CAL에 대한 연 구[14]에 의하면 $\mathrm{PD}$ 와 $\mathrm{CAL}$ 도 연령이 증가할수록 증가하 였다. 브라질 성인의 CAL에 대한 연구[20]에서는 인구의 $36 \%$ 가 $5 \mathrm{~mm}$ 이상, $16 \%$ 는 $7 \mathrm{~mm}$ 이상의 $\mathrm{CAL}$ 을 가지고 있 다고 하였다. 특히 50 대 이상의 인구에서 $5 \mathrm{~mm}$ 이상의 $\mathrm{CAL}$ 은 30대보다 4.9 배, $7 \mathrm{~mm}$ 이상의 $\mathrm{CAL}$ 은 25.4배 높았 다. 칠레의 중년층(33-44세)과 노년층(65-74세)의 $\mathrm{CAL}$ 에 대한 연구에서 중년층 $93.5 \%$, 노년층 $97.6 \%$ 가 $\mathrm{CAL}$ 이 $3 \mathrm{~mm}$ 이상인 site가 1 곳 이상 존재하였다. 그 중 중년층의 $38.7 \%$, 노년층 $69.4 \%$ 는 $6 \mathrm{~mm}$ 이상의 심각한 $\mathrm{CAL}$ 이 있는 site가 1 곳 이상 존재하였다[10]. Jordan의 연구[12]에서는 $\mathrm{PD}$ 와 $\mathrm{CAL}$ 이 $6 \mathrm{~mm}$ 이상인 경우가 50 대에서 각각 $0.5 \%$, $2.9 \%$ 였으나 이번 연구에서는 $\mathrm{PD}$ 와 $\mathrm{CAL}$ 이 $7 \mathrm{~mm}$ 이 이상 인 경우가 각각 $0.7 \%, 2.7 \%$ 였다.

광주광역시 동구 지역에서는 남성의 경우 여성에 비해 2 배 정도 높은 비율의 중증(severe) 치주질환을 가지고 있 었다. 미국에서는 남성이 여성에 비하여 3 배, Jordan에서 는 1.6배 더 높은 중증 치주질환을 가지고 있었다 $[2,12]$. 그 
외 독일의 연구[16]에서도 이와 비슷한 결과가 있었다. 스 웨덴의 연구[11]에 의하면 남성이 더 깊은 $\mathrm{PD}$ 를 가졌다. 이번 연구에서도 $7 \mathrm{~mm}$ 이상의 깊은 $\mathrm{PD}$ 의 비율이 여성에 비해 남성에서 2 배 높았다 핀란드의 65 세 이상 노년층의 치주상태에 관한 연구[17]에서는 PD $7 \mathrm{~mm}$ 이상의 비율이 남자는 $25.4 \%$ 여성은 $12.9 \%$ 였다. 핀란드의 연구에서는 $\mathrm{BOP}$ 가 $16 \%$ 인 비율이 $73 \%$ 였다. 하지만 $\mathrm{BOP}$ 성별이나 연 령에 대해서는 차이가 없었다. 이번 연구에서는 $\mathrm{BOP}$ 가 $25 \%$ 이상인 경우가 $84.4 \%$ 였고 남성에서 $\mathrm{BOP}$ 가 더 높았다.

치주질환은 구강관리습관과 연관되어 있다는 연구가 있 었다[5]. 이번 연구에서 정기적으로 치과를 방문하는 경우 중증 치주질환을 가지는 대상자는 $26.2 \%$ 였고, 방문하지 않는 경우는 $35.2 \%$ 였다. 베트남의 한 연구에서는 치과를 방문한 경우 $29.1 \%$ 가 치주질환을 가지고 있었으며, 한번 도 방문하지 않은 경우에는 $55 \%$ 가 치주질환을 가지고 있 었다[18]. 브라질 성인의 $\mathrm{CAL}$ 에 관한 연구에서는 불규칙 하게 치과를 방문할수록 $\mathrm{CAL}$ 이 심해졌다[15]. 이번 연구 에서도 정기적으로 치과를 방문하지 않을수록 $7 \mathrm{~mm}$ 이하 의 심한 $\mathrm{CAL}$ 의 비율이 증가하였다.

치주질환의 치료는 치석제거술 및 치근면활택술(SRP; Scaling \& Root Planning)을 포함한 비외과적인 치료에서 부터 시작된다. Zandbergen 등에 따르면 스케일링은 $\mathrm{PD}$ 를 감소시키고 $\mathrm{CAL}$ 을 증진시키는데 효과적인 술식이다[4]. 광주광역시 동구 지역에서도 스케일링의 빈도와 치주질환 사이에는 연관성이 있었다. 스케일링을 받지 않을 때보다 정기적으로 받을 때 중증 치주질환의 유병률이 낮았다. 스 케일링을 자주 받는다고 해서 뚜렷하게 중증 치주질환의 유병률이 감소하지는 않았으나, Tukey의 사후 검정 결과 를 보면 상대적으로 스케일링을 자주 받지 않는 집단에서 중증 치주질환을 보였다.

이번 연구에서는 잇솔질 횟수와 치주질환의 유병률 사 이에서도 뚜렷한 상관관계를 보이지는 않았으나 Tukey의 사후검정 결과 잇솔질을 자주 하지 않으면 상대적으로 중 증 치주질환을 가지게 된다고 나타났다. 그리스의 연구 [19]에서는 잇솔질을 자주 할수록 중증 치주질환의 유병률 이 낮았다. 인도의 Meerut지역에 관한 연구에서도 잇솔질 을 하는 경우 CPITN code 3 이 $35 \%$, code 4 가 $15.2 \%$ 로 그 렇지 않은 경우보다 더 낮았다 code $3=36.4 \%$, code 4=17.8\%)[20]. 리투아니아의 연구에서는 하루에 2번 잇솔 질을 하였을 때 깊은 치주낭 형성이 감소되었다[21]. Wu 등[22]의 연구에 따르면, 잇솔질을 한 번도 안하는 경우보 다는 하루에 한 번 할 때 $\mathrm{PD}$ 는 5 배 정도 감소하며, $\mathrm{BOP}$ 도 3 배 감소되었다. 그러나 이번 연구에서는 잇솔질 빈도 와 사이에는 $\mathrm{PD}, \mathrm{CAL}$ 큰 연관이 없었다. 이는 독일의 Pomerania지역의 연구[14]의 결과와 유사하였다.

치주질환은 치아 인접면 부위의 염증에서 시작되므로
인접면 부위의 관리가 중요하며 치실과 치간칫솔을 이용 하면 효과적이다. 그리스[19]와 베트남[5]의 연구에서도 치실을 사용한 경우 중증 치주질환이 감소하였다. Kiger 등[23]과 Christou 등[24]의 연구에서는 치간 칫솔을 이용 할 때 오히려 치실을 이용한 것 보다 치태조절에 효과적 이었다. 이번 연구에서는 O'Leary Index $25 \%$ 이하의 비율 은 치실을 사용한 경우와 치간칫솔을 사용한 경우 각각 $15 \%, 13.3 \%$ 로 앞에 언급된 연구들과는 반대로 치실이 더 효과적으로 치태를 조절한다는 결과가 나왔다. 중증 치주 질환의 유병률도 치실과 치간칫솔에 대해 각각 $17.4 \%$, $23.1 \%$ 로 치실을 사용한 경우 더 낮았다. Lang 등 [25]에 따 르면 치실을 사용할 때 더 $\mathrm{PD}$ 와 $\mathrm{CAL}$ 을 감소시킬 수 있 다고 하였다. 독일의 Pomerania지역의 연구에서도 비슷한 결과를 보였다[14].

2008년에 발표된 구강세정기에 관한 연구에 따르면 구 강세정기는 치태제거에 효과적이지는 않지만 잇솔질과 병 용하면 잇솔질만 하는 것보다는 치은건강에 긍정적인 영 향이 있다[26]. 이번 연구에서도 앞에 언급된 연구와 마찬 가지로 O'Leary Index $25 \%$ 이하의 비율이 $5.3 \%$ 로 치실을 사용할 때 보다 3 배 정도 낮았으며 다른 구강위생용품들 과 비교하였을 때 치태관리에 가장 비효율적이었다. 구강 세정기를 사용하는 경우 중증 치주질환의 유병률은 $31.6 \%$ 로 치실을 사용하는 경우 $17.4 \%$ 인 것과 비교하였을 때 매 우 컸으나 통계적으로 유의미하지는 않았다. 또한 동구민 들 중 구강세정기를 사용하는 인구는 매우 작았기 때문에 구강세정기에 관하여 더 많은 연구가 필요해 보인다. Boyd 등[27]의 연구에 의하면 전동칫솔을 사용할 때 BOP 와 치태지수는 감소하지만 $\mathrm{PD}$ 는 큰 변화가 없었다. Killoy 등[28]의 연구에서는 전동칫솔을 이용하면 일반 칫솔로 잇 솔질을 하는 것보다 $(60 \%)$ O'Leary Index가 $37 \%$ 로 유의미 하게 감소되었다. 이번 연구에서는 전동칫솔을 사용하였 을 때 $\mathrm{BOP}$ 는 전체적으로 향상되었지만, O'Leary Index는 잇솔질을 1 번만 하는 경우보다도 높았다. 중증 치주질환 유병률은 하루에 4번 양치질하는 경우보다도 낮았지만 통 계적으로 유의미 하지 않았다. 구강세정액으로 세척을 하 는 경우 치태와 치은염을 줄여주고 타액과 치은열구의 미생 물 부하도 줄여줄 수 있다는 보고가 있다[29]. 이번 연구에 서는 구강세정액을 사용하였을 때 O'Leary Index $25 \%$ 이하 의 비율이 $18.3 \%$ 로 다른 구강위생용품 보다 가장 효과적으 로 치태관리를 하는 것으로 나타났다. 그러나 치주질환의 유병률에 있어서는 유의미한 결과를 얻지 못하였다.

이번 연구에서는 O'Leary Index, BOP, PD, CAL을 백분 율로 산정하였다. 하지만 이 값들이 잔존 치아 수에 영향 을 받을 수 있었음을 고려하지 못했던 점이 한계점이었다. 이번 연구의 결과로 보아, 치주질환은 나이가 들수록 그리 고 특히 남성인 경우에 유병률이 높았으나 정기적인 치과 
검진을 받고 치실과 치간칫솔과 같은 구강 위생용품을 사 용하면 치주질환 유병률이 감소하였으며 잇솔질 빈도와 스케일링 빈도가 낮을수록 중증 치주질환 유병률이 증가 하는 경향이 있었다.

본 연구의 연구대상이 중, 노년층이었다는 점에서 증령 에 따른 치주질환의 유병률 증가는 노화과정의 일부인 것 으로 생각될 수 있다. 물론 나이에 따른 면역학적, 조직학 적 변화는 치태내 미생물에 대한 숙주반응을 변화시켜 치주 치료에 대한 환자의 반응 능력에 영향을 줄 수도 있다. 노인 에서 관찰되는 치은퇴축, 치주인대 부착소실, 치조골 소실이 노화에 따른 가장 일반적인 변화이지만, 증령에 따른 변화만 으로 건강한 노인에서 치아상실이 일어나지 않는다.

치주건강의 유지 및 예방법은 모든 연령에서 비슷하나 개인의 기능적, 지적 능력에 따라 추가의 시간과 장비, 치 과방문이 필요할 수 있다. 식후의 잇솔질과 치실 사용, 정 기적인 치과검진과 구강세정술을 통해 치주건강을 유지할 수 있다. 중, 노년층으로 갈수록 내과적, 신체적, 행동적 장 애를 가지게 될 가능성이 많아지며, 특히 노년층의 경우 시설에 거주하는 경우도 많다. 또한 노년층일수록 손놀림 이나 시력, 근신경 조화, 신체능력, 인지능력, 기억력이 떨 어지면서 (예, 관절염, 파킨슨 병, 뇌혈관질환, 알츠하이머) 구강위생관리를 매일 수행하기가 어려워질 수 있다. 이러 한 관점에서 볼때, 노인환자의 치주치료는 환자의 태도와 기대감, 이전의 치과치료, 현재 구강건강상태, 구강관리방 법, 전신상태, 복용중인 약물, 신체 및 지적능력, 간병인의 간호 수준에 대한 평가를 필요로 할 것으로 생각된다.

고령화 사회로 진행될수록 중, 노년층의 구강건강에 대 한 인지도가 높아지고 자연치 유지 욕구도 증가될 것이다. 또한 그에 따른 치주질환의 발생할 위험도 증가할 것으로 생각된다. 이에 따라 중, 노년층 치주질환 유병률을 감소 시키기 위한 구강관리습관에 대한 동기유발 및 구강 위생 교육의 중요성이 더욱 강조되며, 정기적인 치과검진 및 구 강관리가 필요할 것으로 생각된다.

\section{결 론}

2008년부터 2010년 동안 광주광역시 동구 50대 이상 지 역민 4025명을 대상으로 실시한 구강 검진과 구강건강 설 문지를 토대로 연구한 결과 대상자들의 치주질환 유병률 은 경증(slight)/ 중등도(moderate)/ 중증(severe) 각각에 대 하여 $10.3 \%, 56,1 \%, 33,6 \%$ 였다. 성별에 따라서는 중증 치 주질환이 남성에서 더 유병률이 높았고, 연령이 증가할수 록 유병률이 증가하였다. 그러나 정기적으로 치과를 방문 하고, 구강위생용품 중에서 치실과 치간칫솔을 사용한 경 우 치주질환 유병률이 감소하였다. 스케일링 빈도와 잇솔
질 횟수가 적을수록 중증 치주질환 유병률은 증가했다. 그 러므로 치주질환 유병률이 높은 중, 노년층에서 구강관리 습관에 대한 동기유발과 정기적인 치과검진 및 구강건강 관리가 필요하다.

\section{Conflict of Interest}

The authors declare that they have no competing interests.

\section{ORCID}

$\begin{array}{ll}\text { Do-Hee Kim } & 0000-0002-9759-6124 \\ \text { Hyun-Ju Chung } & 0000-0001-8461-5093 \\ \text { Ok-Su Kim } & 0000-0001-8528-9314\end{array}$

\section{References}

1. Petersen PE. The World Oral Health Report 2003: continuous improvement of oral health in the 21 st centurythe approach of the WHO Global Oral Health Programme. Community Dentistry and oral epidemiology, 31(s1), 324. doi: 10.1046/j..2003.com122.x.

2. Eke PI, Dye BA, Wei L, Thornton-Evans GO, Genco RJ. Prevalence of periodontitis in adults in the United States: 2009 and 2010. J Dent Res 2012;91:914-920.

3. Lee JB, Yi HY, Bae KH. The association between periodontitis and dyslipidemia based on the fourth Korea National Health and Nutrition Examination Survey. J Clin Periodontol 2013;40:437-442. doi: 10.1111/jcpe.12095.

4. Zandbergen D, Slot DE, Cobb CM, Van der Weijden FA. The clinical effect of scaling and root planing and the concomitant administration of systemic amoxicillin and metronidazole: a systematic review. J Periodontol 2013; 84:332-351. doi: 10.1902/jop.2012.120040.

5. Pham TA, Ueno M, Shinada K, Yanagisawa T, Wright FA, Kawaguchi Y. Periodontal disease and related factors among Vietnamese dental patients. Oral Health Prev Dent 2011;9:185-194.

6. Kweon SS, Shin MH, Jeong SK, Nam HS, Lee YH, Park KS, Zheng W. Cohort Profile: the Namwon study and the Dong-gu study. Int J epidemiol 2014;43:558-567. doi: doi.org/10.1093/ije/dys244.

7. Lindhe J, Lang NP, Karring T. Clinical periodontology and implant dentistry. 5th ed. Seoul: Narae Publishing; 2010. p.129-182.

8. The association of professor for periodontology. Periodontology. 5th ed. Seoul: Koonja Publishing; 2010. 
p.127-140.

9. Norman OH, Franklin GG. Primary Preventive Dentistry. 6th ed. Seoul: Daehan Narae Publishing; 2006. p.290-291.

10. Gamonal J, Mendoza C, Espinoza I, Munoz A, Urzua I, Aranda W, Arteaga O. Clinical attachment loss in Chilean adult population: first Chilean national dental examination survey. J periodontol 2010;81:1403-1410. doi: 10.1902/jop.2010.100148.

11. Renvert S, Persson RE, Persson GR. Tooth loss and periodontitis in older individuals. Results from the Swedish national study on aging and care. J Periodontol 2013; 84:1134-1144. doi: 10.1902/jop.2012.120378.

12. Ababneh KT, Hwaij ZMA, Khader YS. Prevalence and risk indicators of gingivitis and periodontitis in a MultiCentre study in North Jordan: a cross sectional study. BMC Oral Health 2012;12:1. doi: 10.1186/1472-6831$12-1$.

13. Torrungruang K, Tamsailom S, Rojanasomsith K, Sutdhibhisal S, Nisapakultorn K, Vanichjakvong O, Prapakamol S, Premsirinirund T, Pusiri T, Jaratkulangkoon O, Unkurapinun N, Sritara P. Risk indicators of periodontal disease in older Thai adults. J Periodontol 2005;76:558565. doi: 10.1902/jop.2005.76.4.558.

14. Gätke D, Holtfreter B, Biffar R, Kocher T. Five-year change of periodontal diseases in the Study of Health in Pomerania (SHIP). J Clin Periodontol 2012;39:357-367. doi: 10.1111/j.1600-051X.2011.01849.x.

15. Susin C, Vecchia CD, Oppermann RV, Haugejorden O, Albandar JM. Periodontal attachment loss in an urban population of Brazilian adults: effect of demographic, behavioral, and environmental risk indicators. J Periodontol 2004;75:1033-1041. doi:10.1902/jop.2004.75.7.1033.

16. Holtfreter B, Kocher T, Hoffmann T, Desvarieux M, Micheelis W. Prevalence of periodontal disease and treatment demands based on a German dental survey (DMS IV). J Clin Periodontol 2010;37:211-219. doi: 10.1111/j.1600-051X.2009.01517.x.

17. Syrjälä, AM, Ylöstalo P, Knuuttila M. Periodontal condition of the elderly in Finland. Acta Odontol Scand 2010;68:278-283.

18. Do LG, Spencer AJ, Roberts-Thomson KF, Trinh HD, Nguyen TT. Oral health status of Vietnamese adults: findings from the National Oral Health Survey of Vietnam. Asia Pac J Public Health 2011;23:228-236.

19. Mamai-Homata E, Polychronopoulou A, Topitsoglou V, Oulis C, Athanassouli T. Periodontal diseases in Greek adults between 1985 and 2005-Risk indicators. Int Dent
J 2010;60:293-299. doi: 10.1922/IDJ_2525Homata07.

20. Singh A, Agarwal V, Tuli A, Khattak BP. Prevalence of chronic periodontitis in Meerut: A cross-sectional survey. J Indian Soc Periodontol 2012;16:529. doi: 10.4103/ 0972-124X.106895.

21. Vysniauskaite S, Vehkalahti MM. Impacts of toothbrushing frequency on periodontal findings in a group of elderly Lithuanians. Oral Health Prev Dent 2009;7:129.

22. Wu YM, Liu J, Sun WL, Chen LL, Chai LG, Xiao X, Cao Z. Periodontal status and associated risk factors among childbearing age women in Cixi City of China. J Zhejiang Univ Sci B 2013;14:231-239. doi: 10.1631/jzus. B1200034.

23. Kiger RD, Nylund K, Feller RP. A comparison of proximal plaque removal using floss and interdental brushes. J Clin Periodontol 1991;18:681-684. doi: 10.1111/ j.1600-051X.1991.tb00109.x.

24. Christou V, Timmerman MF, Van der Velden U, Van der Weijden FA. Comparison of different approaches of interdental oral hygiene: Interdental brushes versus dental floss. J Periodontol 1998;69:759-764. doi:10.1902/ jop.1998.69.7.759.

25. Lang WP, Ronis DL, Farghaly MM. Preventive behaviors as correlates of periodontal health status. J Public Health Dent 1995;55:10-17. doi: 10.1111/j.1752-7325. 1995.tb02324.x.

26. Husseini A, Slot D, Weijden GV. The efficacy of oral irrigation in addition to a toothbrush on plaque and the clinical parameters of periodontal inflammation: a systematic review. Int J Dent Hyg 2008;6:304-314. doi: 10.1111/j.1601-5037.2008.00343.x.

27. Boyd RL, Murray P, Robertson PB. Effect on periodontal status of rotary electric toothbrushes vs. manual toothbrushes during periodontal maintenance: I. Clinical results. J Periodontol 1989;60:390-395. doi:10.1902/jop. 1989.60.7.390.

28. Killoy WJ, Love JW, Love J, Fedi PF, Tira DE. The effectiveness of a Counter-rotary action powered toothbrush and conventional toothbrush on plaque removal and gingival bleeding: A short term study. J Periodontol 1989;60:473-477. doi:10.1902/jop.1989.60.8.473.

29. Escribano M, Herreral D, Morante S, Teughels W, Quirynen M, Sanz M. Efficacy of a low-concentration chlorhexidine mouth rinse in non-compliant periodontitis patients attending a supportive periodontal care programme: a randomized clinical trial. J Clin Periodontol 2010;37:266-275. doi: 10.1111/j.1600-051X.2009.01521.x. 